\title{
ANALISIS YURIDIS PUTUSAN MAHKAMAH KONSTITUSI NOMOR 16/PUU-XVI/2018 TENTANG PEMBATALAN PERLUASAN KEWENANGAN MAHKAMAH KEHORMATAN DEWAN
}

\author{
Yohanes Nafta Irawan, Retno Saraswati, Esmi Warassih Pujirahayu \\ Fakultas Hukum, Universitas Diponegoro \\ yohanes_nafta@yahoo.com
}

\begin{abstract}
This research analyzes the Constitutional Court Decision Number 16/PUU-XVI/2018 that has been canceled Article 122 letter l and Article 245 section (1) from the Law Number 2 of 2018. Article 122 letter $l$ is related to legal steps or other steps that can be taken by The Council Honor Court in the event that there is individuals, groups of people, or legal entities who criticize the House of Representatives or members of the House of Representatives, while Article 245 section (1) relates to the consideration given by the Council Honor Court in the event of a summons or request for investigation into members of the House of Representatives. Both articles are considered unconstitutional and contain an extension of the authority of the Council Honor Court. The appearance of the two articles was influenced by the political configuration of the authoritarian House of Representatives and the naming of the Council Honor Court which deemed inappropriate.
\end{abstract}

Keywords: The Council Honor Court; The Constitutional Court Decision; Expansion of Authority

\begin{abstract}
Abstrak
Penelitian ini menganalisis Keputusan Mahkamah Konstitusi Nomor 16/PUU-XVI/2018 yang membatalkan Pasal 122 huruf 1 dan Pasal 245 ayat (1) Undang-undang Nomor 2 Tahun 2018. Pasal 122 huruf 1 terkait dengan langkah hukum atau langkah lain yang dapat diambil oleh Mahkamah Kehormatan Dewan dalam hal ada orang perseorangan, sekelompok orang, atau badan hukum yang merendahkan kehormatan Dewan Perwakilan Rakyat atau anggota Dewan Perwakilan Rakyat, sedangkan Pasal 245 ayat (1) terkait dengan pertimbangan yang diberikan oleh Mahkamah Kehormatan Dewan dalam hal terjadi pemanggilan atau permintaan pemeriksaan terhadap anggota Dewan Perwakilan Rakyat. Kedua pasal tersebut dianggap inkonstitusional dan mengandung perluasan kewenangan Mahkamah Kehormatan Dewan. Kemunculan kedua pasal tersebut dipengaruhi oleh konfigurasi politik Dewan Perwakilan Rakyat yang otoriter dan penamaan Mahkamah Kehormatan Dewan yang dinilai kurang tepat.
\end{abstract}

Kata Kunci: Mahkamah Kehormatan Dewan; Keputusan Mahkamah Konstitusi; Perluasan Kewenangan

\section{A. Pendahuluan}

Pembentukan hukum dalam arti undang-undang merupakan aktivitas penting dalam negara hukum. Proses pembuatan undang-undang didefinisikan sebagai rentetan kejadian yang bermula dari perencanaan, pengusulan, pembahasan, pengesahan dan pengundangan (Setyowati 2010). Norma hukum yang hendak dituangkan dalam rancangan peraturan perundang-undangan, benar-benar telah disusun berdasarkan pemikiran yang matang dan perenungan yang memang mendalam, semata-mata untuk kepentingan umum (public interest), bukan kepentingan pribadi 
atau golongan (Asshiddiqie 2006).

Kekuasaan atau pembentukan hukum saat ini dipegang oleh Dewan Perwakilan Rakyat (DPR) yang berkedudukan sebagai lembaga legislatif sebagaimana telah diamanatkan oleh Pasal 20 ayat (1) UUD NRI 1945. Hal ini terkait dengan fungsi legislasi DPR.

Rapat Paripurna DPR pada 14 Februari 2018 telah mengesahkan Undang-undang Nomor 2 Tahun 2018 Tentang Perubahan Kedua atas Undang-undang Nomor 17 Tahun $2014 \quad$ Tentang Majelis Permusyawaratan Rakyat, Dewan Perwakilan Rakyat, Dewan Perwakilan Daerah, dan Dewan Perwakilan Rakyat Daerah. Undang-undang ini kemudian mendapat sorotan yang besar dari masyarakat terkait dengan beberapa pasal yang dinilai kontroversial yang diantaranya bermuara pada penambahan kewenangan baru oleh DPR kepada Mahkamah Kehormatan Dewan (MKD) sebagaimana tercantum dalam Pasal 122 huruf 1 dan Pasal 245 ayat (1). Berdasarkan pada Pasal 122 huruf 1, MKD dapat mengambil langkah hukum dan/atau langkah lain terhadap orang perseorangan, kelompok orang, atau badan hukum yang merendahkan kehormatan DPR dan anggota DPR. Hal ini tentu menuai kontroversi karena seakan-akan menampilkan parlemen yang antikritik dan dikhawatirkan akan membatasi kebebasan pers dengan menjerat kemerdekaan pers dalam pemberitaan tentang DPR. Sedangkan Pasal 245 ayat (1) menyatakan bahwa pemangggilan atau permintaan pemeriksaan oleh para penegak hukum terhadap anggota DPR harus mendapatkan persetujuan tertulis dari Presiden yang sebelumnya harus mendapat pertimbangan dari MKD terlebih dahulu. Pasal ini juga dianggap kontroversial, karena anggota MKD berasal dari internal DPR, sehingga muncul kekhawatiran masyarakat bahwa MKD akan berusaha melindungi anggota DPR dengan menghalang-halangi pemeriksaan yang akan dilakukan oleh para penegak hukum. Kedua pasal tersebut dinilai mengandung perluasan kewenangan MKD karena kewenangan baru yang diberikan melalui kedua pasal tersebut, tidak sesuai dengan kedudukan MKD sebagai lembaga etik DPR. Akhirnya, melalui Putusan MK Nomor 16/PUUXVI/2018, kedua pasal tersebut dinyatakan bertentangan dengan UUD NRI Tahun 1945 dan tidak mempunyai kekuatan hukum mengikat lagi.

Menurut M. Guntur Hamzah perluasan kewenangan dapat dimaknai sebagai penambahan kewenangan pada suatu peraturan yang disebabkan adanya perluasan atau perubahan batasan konsep yang telah diatur oleh peraturan sebelumnya. (Hamzah n.d.)

DPR dalam melaksanakan tugas dan kewenangannya perlu memperhatikan atau berpedoman pada Teori Mandat dan Teori Perwakilan. Teori Mandat menyatakan bahwa cara melaksanakan kekuasaan negara ialah senantiasa mengingat kehendak dan keinginan rakyat. Jadi, tiap tindakan dalam melaksanakan kekuasaan negara tidak boleh bertentangan dengan kehendak dan kepentingan rakyat, bahwa sedapat mungkin berusaha memenuhi segala keinginan rakyat. (Kansil 2003) Sedangkan Teori Perwakilan menyatakan bahwa hubungan penguasa (wakil) dan rakyat (terwakil) harus harmonis serta harus memiliki tanggungjawab penuh kepada seluruh masyarakat dalam menjalankan roda pemerintahan, guna terciptanya keseimbangan dalam menjalankan roda pemerintahannya. (Kantaparwira 2007)

MKD merupakan lembaga etik DPR yang bertujuan untuk menjaga serta menegakkan kehormatan dan keluhuran martabat DPR. Sebelum diresmikan sebagai alat kelengkapan DPR yang bersifat tetap, lembaga ini bernama Dewan Kehormatan (DK) yang pembentukannya hanya bersifat sementara (adhoc). Kemudian DK berganti nama menjadi Badan Kehormatan (BK) pada tahun 2003 dan terakhir diubah menjadi Mahkamah Kehormatan Dewan (MKD) seperti saat ini (Habibi 2014) pada tahun 2014 atau sejak diterbitkannya Undang-undang No. 17 Tahun 2014 (UU MD3). Lembaga etik ini dibentuk untuk menjawab tanggapan atas sorotan publik 
terhadap kinerja buruk sebagian anggota DPR dan beberapa kasus pelanggaran kode etik oleh anggota DPR (Ardi 2017). Kehadiran MKD sebagai penegak etik adalah salah satu living ethics (Imani 2016). Teori-teori hukum yang menguatkan keberadaan badan pengawas etika dalam lembaga perwakilan, antara lain Teori Organisasi Negara, Teori etika, dan Teori Sanksi (Habibi 2014).

Dilihat dari teori organisasi negara, Jimly Asshiddiqie (Habibi 2014) berpendapat bahwa ide pembaharuan yang menyertai pembentukan lembaga baru itu pada umumnya didasarkan atas dorongan untuk mewujudkan kinerja yang cepat, disamping adanya momentum politik yang memberikan kesempatan untuk dilakukannya demokratisasi di segala bidang. Berdasarkan teori etika, unsur etika sangat menyatu dalam sebuah norma hukum, jika kedua unsur ini dilanggar, tentu sanksi akan ditegakkannya. MKD bekerja berdasarkan beberapa undang-undang, surat keputusan dan tata tertib DPR-RI, yang memberlakukan sanksi sebagai tindakan yang tepat dalam mengawasi etika anggota Dewan bila melakukan pelanggaran terhadap kode etik dan tata tertib DPR-RI atau hal-hal yang berhubungan dengan penyalahgunaan kekuasaan (a buse of power). Sedangkan menurut teori sanksi yang dipelopori oleh Emile Durkheim (1858-1917) (Habibi 2014), norma hukum harus dipatuhi, kalau dilanggar ada sanksinya, begitu pula norma moral wajib dipatuhi; suara hati manusia menegaskan itu.

Berdasarkan pemaparan di atas, Penulis sangat tertarik melakukan penelitian untuk menganalisis perkembangan lembaga etik DPR-RI sejak awal pembentukannya hingga saat ini, serta menganalisis Pertimbangan Putusan MK Nomor 16/PUU-XVI/2018 dalam membatalkan perluasan kewenangan MKD yang terkandung dalam Pasal 122 huruf 1 dan Pasal 245 ayat (1) Undangundang No. 2 Tahun 2018. Hal ini sangat penting untuk kemudian dibahas mengingat banyaknya tanggapan yang memperlihatkan ketakutan dan kekhawatiran masyarakat dengan adanya perluasan kewenangan MKD dan minimnya pengetahuan masyarakat awam terhadap kedudukan dan peranan MKD. Rumusan masalah dalam penulisan ini dapat dirumuskan sebagai berikut :

1. Bagaimana perkembangan lembaga etik DPR-R sejak awal pembentukannya hingga saat ini?

2. Bagaimana pertimbangan Putusan $\mathrm{MK}$ Nomor 16/PUU-XVI/2018 dalam membatalkan perluasan kewenangan MKD?

\section{B. Metode Penelitian}

Metode pendekatan yang digunakan dalam penelitian ini adalah pendekatan yuridis normatif. Pendekatan yuridis adalah suatu pendekatan yang mengacu pada hukum yang dikonsepkan sebagai peraturan perundang-undangan yang mengandung norma-norma tertulis. Sedangkan pendekatan teks-teks normatif adalah pendekatan yang dilakukan dengan cara meneliti bahan pustaka atau bahan hukum terhadap asas-asas hukum yang penerapannya yakni dengan mengkaji norma-norma hukum dalam peraturan perundang-undangan yang terkait dengan masalah-masalah yang akan diteliti. Metode pendekatan ini juga dilakukan dengan menggunakan metode komparatif atau metode perbandingan.

Spesifikasi penelitian yang digunakan dalam penulisan hukum ini adalah Preskriptif Analisis, yaitu mempelajari tujuan hukum, nilai-nilai keadilan, validitas aturan hukum, konsep-konsep hukum, dan norma-norma hukum (Marzuki 2010) untuk memberikan argumentasi atas hasil penelitian yang dilakukan. Bahan-bahan hukum yang digunakan dalam penelitian ini yakni bahan hukum primer yang terdiri dari undang-undang, peraturan DPR, dan Putusan MK serta bahan hukum sekunder yang terdiri dari buku, pendapat para sarjana, jurnal dan artikel. Setelah dikumpulkan, bahan hukum selanjutnya dianalisis dengan metode kualitatif yakni dengan dilakukan pembahasan, pemeriksaan dan pengelompokan ke dalam bagian-bagian 
tertentu yang kemudian disajikan dalam bentuk uraian-uraian yang disusun secara sistematis, sehingga secara keseluruhan merupakan satu kesatuan yang utuh sesuai dengan kebutuhan penelitian.

\section{Hasil dan Pembahasan}

1. Perkembangan Lembaga Etik DPRRI sejak Awal Pembentukan hingga Saat Ini

\section{a. Periode 1999-2002}

Lembaga etik DPR pada periode ini dikenal dengan sebutan Dewan Kehormatan (DK) dan hanya bersifat sementara (adhoc). Ada 3 (tiga) peraturan yang mengatur keberadaan DK pada periode ini, yakni Undang-undang No. 4 Tahun 1999 (Susduk MPR, DPR \& DPRD), Keputusan DPR-RI No. 16/DPR RI/I/1999-2000 Tentang peraturan Tata Tertib DPR dan Keputusan DPR-RI No. 03A/DPR RI/I/2001-2002 Tentang Peraturan Tata Tertib DPR-RI. DK memiliki tugas untuk melakukan penelitian terhadap laporan pengaduan atas dugaan pelanggaran yang dilakukan oleh anggota DPR, memberikan laporan mengenai perkembangan penelitian dan laporan akhir berupa rekomendasi kepada pimpinan DPR dan selanjutnya pimpinan DPR-lah yang akan menetapkan sanksi bagi anggota DPR yang bersangkutan. Tugas DK diangggap selesai setelah menyampaikan rekomendasi kepada pimpinan DPR. DK memiliki wewenang untuk memanggil anggota DPR yang bersangkutan, pelapor, saksi, atau pihak-pihak lain.

\section{b. Periode 2003-2013}

Lembaga Etik DPR mengalami perkembangan yang cukup signifikan pada periode ini dengan berganti nama menjadi Badan Kehormatan (BK) dan pembentukannya bersifat tetap. Ada beberapa peraturan yang mengatur keberadaan BK pada periode ini, yakni Undang-undang No. 22 Tahun 2003, Keputusan DPR-RI No. 08/DPR RI/I/2005.2006 Tentang Peraturan Tata Tertib DPR-RI, Undang-undang No. 27 Tahun 2009 (UU MD3 Tahun 2009), dan Peraturan DPR No. 2 Tahun 2011 Tentang
Tata Beracara BK. Pada Periode ini, BK tidak hanya bertugas melakukan penyelidikan dan verifikasi atas adanya pengaduan saja, melainkan juga penanganan terhadap pelanggaran yang tidak memerlukan pengaduan. Pada Periode ini, BK juga mendapatkan penambahan tugas untuk melakukan evaluasi dan penyempurnaan peraturan DPR tentang kode etik DPR. BK memiliki wewenang untuk memanggil para pihak yang terkait dan melakukan kerjasama dengan lembaga lain. Selanjutnya, penetapan rehabilitasi atau sanksi terhadap anggota DPR yang dilaporkan, tidak lagi menjadi kewenangan Pimpinan DPR, melainkan kewenangan BK.

\section{c. Periode 2014 - Sekarang}

Lembaga etik DPR kembali mengalami pergantian nama menjadi Mahkamah Kehormatan Dewan (MKD). Ada 3 (tiga) peraturan yang mengatur kedudukan MKD pada periode ini, yakni Undang-undang No. 17 Tahun 2014 (UU MD3), Peraturan DPR No. 2 Tahun 2015 (Tata Beracara MKD), dan Undang-undang No. 2 Tahun 2018. MKD bertujuan untuk menjaga serta menegakkan kehormatan dan keluhuran martabat DPR sebagai lembaga perwakilan rakyat. MKD bertugas untuk melakukan penanganan atas adanya pengaduan terhadap anggota DPR dan juga terhadap pelanggaran yang tidak memerlukan pengaduan. MKD berwenang untuk memanggil pihak yang terkait dan melakukan kerjasama dengan lembaga lain. Melalui Undang-undang No. 2 Tahun 2018, MKD tidak hanya memiliki fungsi penindakan saja, melainkan juga fungsi pencegahan dan pengawasan, sehingga, MKD menerima beberapa penambahan tugas dan wewenang terkait dengan lahirnya fungsi tersebut. Namun, ada beberapa penambahan kewenangan yang kemudian menjadi sorotan masyarakat yakni terkait dengan Pasal 122 huruf 1 dan Pasal 245 ayat (1) Undang-undang No. 2 Tahun 2018 karena diduga mengandung perluasan kewenangan. 


\section{Pertimbangan Mahkamah Konstitusi dalam Membatalkan Perluasan Kewenangan Mahkamah Kehormatan Dewan}

MKD mendapatkan banyak sorotan dari masyarakat pasca disahkannya Undang-undang No. 2 Tahun 2018. Di dalam undang-undang tersebut terdapat 2 (dua) pasal yang diduga mengandung perluasan kewenangan MKD dan dinilai inkonstitusional, yakni Pasal 122 huruf 1 dan Pasal 245 ayat (1) Undang-undang No. 2 Tahun 2018.

Pasal 122 huruf l, yang menyatakan: "mengambil langkah hukum dan/atau langkah lain terhadap orang perseorangan; kelompok orang, atau badan hukum yang merendahkan kehormatan DPR dan anggota DPR".

Pasal 245 ayat (1), yang menyatakan : "Pemanggilan dan permintaan keterangan kepada anggota DPR sehubungan dengan terjadinya tindak pidana yang tidak sehubugan dengan pelaksanaan tugas sebagaimana dimaksud dalam Pasal 224 harus mendapatkan persetujuan tertulis dari Presiden setelah mendapat pertimbangan dari Mahkamah Kehormatan Dewan".

Namun, akhirnya pada tanggal 28 Juni 2018, MK mengeluarkan Putusan MK Nomor 16/PUU-XVI/2018 yang membatalkan kedua pasal tersebut. Dalam membatalkan kedua pasal tersebut, MK memiliki pandangan tersendiri. Terkait dengan Pasal 122 huruf 1, MK memiliki pandangan bahwa :

1) MKD bukanlah alat kelengkapan yang dimaksudkan sebagai tameng untuk mengambil langkah terhadap orang perorangan yang dinilai telah merendahkan martabat DPR atau anggota DPR dan penambahan tugas MKD yang demikian dapat menimbulkan rasa takut bagi masyarakat untuk berpartisipasi dalam turut serta mencegah terjadinya pelanggaran kode etik yang dilakukan oleh anggota DPR.
2) Pasal 122 huruf 1 UU MD, khususnya frasa "merendahkan kehormatan DPR dan anggota DPR" dirumuskan dengan norma yang sangat umum, tidak jelas dan multitafsir.

3) Terkait dengan frasa "mengambil langkah hukum" dalam Pasal 122 huruf 1 secara normatif tidak terdapat penjelasan yang pasti. Apakah frasa tersebut berarti MKD akan melakukan langkah hukum dengan menindaklanjuti sendiri semua tindakan atau ucapan masyarakat yang dinilai merendahkan martabat anggota DPR dan institusi DPR, atau MKD akan melaporkan kepada institusi penegak hukum.

4) Perubahan Pasal 122 UU MD3 ini juga telah menggeser peran MKD dari awalnya sebagai lembaga penegak etik internal menjadi juga mencakup pihak eksternal. Selain itu, pasal ini telah menyebabkan bergesernya subjek utama yang diatur sebagai pihak yang bertindak sebagai pelanggar etik DPR yang menyebabkan kehormatan DPR menjadi berkurang, yaitu anggotaanggota DPR.

\section{Komentar :}

Dalam hal ini, Penulis setuju dan memiliki pendapat yang berbanding lurus sekaligus mendukung pertimbangan MK dalam membatalkan Pasal 122 huruf 1 . Penulis berpendapat bahwa Pasal 122 huruf 1 mengandung perluasan kewenangan MKD.

Terkait dengan Pasal 122 huruf 1, Putusan MK Nomor 013-022/PUU-VI/2006 mengenai penghinaan terhadap Presiden dan/atau Wakil Presiden dan Putusan MK Nomor 31/PUU-XIII/2015 mengenai penghinaan terhadap pejabat telah menyatakan bahwa penghinaan dan pencemaran terhadap jabatan sudah tidak ada sebab bertentangan dengan prinsip persamaan kedudukan di hadapan hukum. Ketentuan atau ukuran terhadap penghinaan telah dikembalikan pada pengaturan di dalam KUHP sebagai delik aduan dan menjadi hak perorangan (personalisasi), sehingga MKD sebagai lembaga etik DPR 
tentu tidak dapat mewakili 560 anggota DPR dalam hal terjadi tindakan yang merendahkan kehormatan DPR atau anggota DPR. Pengaduannya harus diajukan secara individu oleh pihak yang merasa dihina kehormatannya. Dalam KUHP, pencemaran nama baik diatur pada Bab XVI tentang Penghinaan yang termuat dalam Pasal 310 s.d 321 KUHP. Melihat pada penjelasan R. Soesilo dalam Pasal 310 KUHP, dapat kita lihat bahwa KUHP membagi enam macam penghinaan, yakni(R. Soesilo 1991) penistaan, penistaan dengan surat, fitnah, penghinaan ringan, pengaduan palsu atau pengaduan fitnah, dan perbuatan fitnah.

Jika mengacu pada Pasal 121 huruf A Undang-undang No. 2 Tahun 2018, MKD memiliki kewenangan melakukan pencegahan, pengawasan dan penindakan. Tentu saja yang dimaksudkan dalam Pasal 121 huruf A ditujukan kepada anggota DPR RI yang melanggar kode etik atau norma hukum, artinya berlaku dilingkungan internal lembaga DPR RI. Dengan demikian, ketika MKD melakukan langkah hukum/langkah lain terhadap orang perseorangan, kelompok orang, badan hukum, menjadi sangat rancu dan bertentangan dengan hakikat pasal 121 huruf A.(Sofian 2018) Berdasarkan pemaparan di atas, Penulis berpendapat bahwa penambahan kewenangan MKD ini tidaklah relevan dengan tugas, kewenangan, dan fungsi MKD sebagai lembaga pengawas etik DPR, sehingga termasuk dalam perluasan kewenangan.

Selanjutnya, terkait dengan Pasal 245 ayat (1), MK berpendapat bahwa pasal tersebut bertentangan dengan UUD NRI Tahun 1945 karena kontradiktif dengan filosofi dan hakikat pemberian hak imunitas anggota DPR yang secara konteskstual seharusnya menjadi dasar pemikiran atau latar belakang pembentukan MKD. Syarat adanya pertimbangan MKD bertentangan dengan Putusan MK Nomor 76/PUU$\mathrm{XII} / 2014$.

\section{Komentar :}

Dalam hal ini, Penulis juga pun setuju dan memiliki pendapat yang berbanding lurus sekaligus mendukung pertimbangan MKD dalam membatalkan Pasal 245 ayat (1). Penulis berpendapat bahwa pasal tersebut juga mengandung perluasan kewenangan MKD.

Terkait dengan kewenangan MKD dalam Pasal 245 ayat (1), Penulis menilai bahwa proses pemanggilan dan permintaan keterangan termasuk dalam suatu rangkaian proses hukum yang menjadi kewenangan para penegak hukum. Sehingga pemberian pertimbangan oleh MKD tersebut merupakan suatu bentuk intervensi yang dilakukan oleh MKD sebagai lembaga etik terhadap ranah kewenangan lembaga yuridis atau lembaga penegak hukum. Terkait dengan ranah kewenangan lembaga etik dan lembaga yuridis, di dalam kehidupan bermasyarakat dikenal 4 jenis norma, yakni norma agama, norma kesusilaan, norma kesopanan, dan norma hukum.(Ziyadi 2017) Norma hukum yang kedudukannya lebih tinggi memiliki lembaga penegaknya sendiri, yakni para penegak hukum. Sedangkan norma yang tingkatannya berada di bawah norma hukum dan belum menjadi hukum inilah yang disebut etika atau disiplin yang menjadi ranah lembaga etik. Berdasarkan pada pemaparan di atas, Penulis berpendapat bahwa penambahan wewenang MKD dalam Pasal 245 ayat (1), telah keluar dari konsep MKD sebagai lembaga etik DPR sehingga dapat dikatakan sebagai perluasan kewenangan. Pemberian pertimbangan oleh MKD dalam hal terjadi pemanggilan atau pemeriksaan anggota DPR dikhawatirkan akan menghambat jalannya proses hukum dan dapat menjadi sarana perlindungan anggota DPR dari para penegak hukum mengingat bahwa anggota MKD berasal dari internal DPR.

Pasal ini juga dianggap inkonstitusional karena bertentangan dengan Putusan MK Nomor 76/PUU XII/2014 yang membatalkan Pasal 245 ayat (1) Undangundang No. 17 Tahun 2014. Awalnya, berdasarkan pasal tersebut pemanggilan dan 
permintaan keterangan untuk penyidikan terhadap anggota DPR yang diduga melakukan tindak pidana harus mendapat persetujuan tertulis dari MKD. Ketentuan ini kemudian dinyatakan oleh MK inkonstitusional bersyarat sepanjang frase I"persetujuan tertulis dari Mahkamah Kehormatan Dewanl" tidak dimaknai ।"persetujuan tertulis dari Presidenl".

Pertimbangan dari MKD dinilai rawan terjadinya konflik kepentingan. Cukup banyak pendapat dikalangan masyarakat bahwa etika anggota DPR sulit ditegakkan, anggota DPR kerap melanggar kode etik, namun selalu bebas tanpa sanksi. Dari data yang diliput media, BK DPR telah menerima 68 pengaduan terkait berbagai dugaan pelanggaran yang dilakukan oleh anggota DPR dalam periode 2009-2014. Dari 68 pengaduan yang diterima, BK DPR hanya mendindak 45 kasus pelanggaran kode etik. Dari 68 pengaduan tersebut, 23 pengaduan tidak ditindaklanjuti karena tidak memenuhi persayaratan administrasi dan bukan merupakan pelanggaran kode etik, serta alamat fiktif sehingga sulit ditindaklanjuti karena tidak bisa dihubungi. (Susilo 2012)

Penulis selanjutnya berpandangan bahwa Pasal 122 huruf 1 dan Pasal 245 ayat (1) Undang-undang No. 2 Tahun 2018 yang mengandung perluasan kewenangan MKD merupakan produk hukum ortodoks/konservatif yang lahir karena pengaruh konfigurasi politik DPR-RI yang otoriter. Sebab, menurut Mahfud MD, konfigurasi politik yang demokratis akan melahirkan produk hukum yang otonom, sedangkan konfigurasi politik yang otoriter akan menghasilkan produk hukum yang ortodoks/konservatif. (MD 1999)

Konfigurasi politik otoriter adalah konfigurasi yang menempatkan pemerintah pada posisi yang sangat dominan dengan sifat yang intervensionis dalam penentuan dan pelaksanaan kebijakan negara sehingga potensi dan aspirasi masyarakat tidak teragregasi dan terartikulasi secara proporsional, dan pers tidak memiliki kebebasan dan senantiasa dibawah kontrol pemerintah dan bayang-bayang pembreidelan. (MD 1999) Produk hukum konservatif/ortodoks adalah produk hukum yang karakternya mencerminkan visi politik pemegang kekuasaan, sehingga pembuatannya tidak mengundang partisipasi dan aspirasi masyarakat secara sungguhsungguh. Rumusan materi hukumnya biasanya bersifat pokok-pokok saja sehingga dapat diinterpretasi pemerintah menurut visi dan kehendaknya sendiri dengan berbagai peraturan pelaksanaan. (MD 1999)

Konfigurasi politik DPR-RI termasuk dalam jenis konfigurasi politik otoriter. Sebab, sikap partai-partai di DPR dalam membentuk Undang-undang No. 2 Tahun 2018, bertentangan dengan sikap demokratis, prinsip kedaulatan rakyat dan prinsip perwakilan. DPR dalam membentuk undang-undang ini juga terkesan sangat intervensionis dan lebih mengedepankan kepentingan individu atau golongan semata daripada kepentingan rakyat. Hal ini tentu bertentangan dengan AD/ART masingmasing partai, teori Mandat dan teori Perwakilan yang seharusnya menjadi pedoman anggota DPR dalam melaksanakan tugas dan wewenangnya.

Pasal 122 huruf 1 dan Pasal 245 adalah produk hukum yang ortodoks/konservatif karena dapat mengancam kebebasan pers dan sangat terbuka untuk dapat diinterpretasikan berdasarkan kehendak dan visi DPR sendiri.

Penulis juga berpendapat bahwa pemberian nama pada lembaga etik DPR-RI akan berpengaruh terhadap kewenangankewenangan yang akan diterima. Pemberian nama "Mahkamah Kehormatan Dewan" pada lembaga etik DPR-RI saat ini dirasa kurang tepat. Sebab, MKD merupakan lembaga etik DPR-RI yang ruang lingkupnya hanya berlaku di internal DPR, yakni memeriksa, memutus, dan mengadili perkara pelanggaran kode etik yang dilakukan oleh anggota DPR, bukannya memutus sengketa hukum.

MKD tentu berbeda dengan Mahkamah Agung dan Mahkamah Konstitusi yang memiliki kedudukan sebagai pemegang 
kekuasaan kehakiman di Indonesia yang memiliki tugas untuk menguji peraturan perundang-undangan dibawah undangundang terhadap undang-undang dan menguji undang-undang terhadap undangundang dasar. Penamaan yang kurang tepat dapat berpotensi menimbulkan terjadinya perluasan kewenangan ataupun ketimpangan wewenang dengan lembaga-lembaga lain, sehingga sangat penting untuk diperhatikan dan dipertimbangkan.

\section{Simpulan dan Saran}

1. Simpulan

a. Kewenangan Lembaga Etik DPR Sejak Awal Pembentukannya hingga Saat ini.

Sejak awal pembentukannya yakni pada tahun 1999 hingga saat ini, MKD terus berevolusi dan mengalami perkembangan. Tidak hanya mengalami pergantian nama, tetapi juga perubahan sifat pembentukannya. MKD juga mengalami penambahan wewenang bahkan perluasan kewenangan.

\section{b. Pertimbangan MK dalam Membatalkan Perluasan Kewenangan MKD}

Melalui Putusan MK Nomor 16/PUU-XVI/2018, MK membatalkan Pasal 122 huruf 1 karena dirumuskan dengan norma yang sangat umum, tidak jelas dan multitafsir dan menimbukan rasa takut ditengah masyarakat. Pasal ini juga telah menggeser peran MKD menjadi lembaga etik yang mencakup pihak eksternal. Putusan ini juga membatalkan Pasal 245 ayat (1) karena kontradiktif dengan filosofi dan hakikat pemberian hak imunitas anggota DPR. Kedua pasal tersebut dinilai mengandung perluasan kewenangan, sebab tidak sesuai dengan kedudukan MKD sebagai lembaga etik DPR-RI.

Konfigurasi politik DPR-RI yang otoriter dan penamaan "Mahkamah Kehormatan Dewan" yang dinilai kurang tepat menjadi faktor pendorong lahirnya Pasal 122 huruf 1 dan Pasal 245 ayat (1).

\section{Saran}

Berdasarkan hasil pembahasan penelitian dan kesimpulan di atas maka Penulis memberikan saran-saran sebagai berikut :

a. DPR dan Presiden harus segera melakukan perubahan terhadap undangundang No. 2 Tahun sebagai upaya tindaklanjut dari adanya Putusan MK Nomor 16/PUU-XVI/2018.

b. Penambahan tugas dan kewenangan MKD harus disesuaikan dengan kedudukan dan hakikat MKD sebagai suatu lembaga etik DPR untuk menghindari terjadinya percampuran atau intervensi terhadap lembagalembaga lainnya.

c. Komposisi keanggotaan MKD sebaiknya tidak hanya berasal dari unsur internal DPR saja, melainkan juga melibatkan unsur-unsur eksternal DPR di dalamnya.

d. Penelitian dan pengembangan lebih lanjut dapat dilakukan untuk menganalisis akibat hukum dan penegakan hukum yang ditimbulkan dari bentuk konfigurasi politik DPR yang otoriter serta menganalisis penamaan yang tepat untuk lembaga etik DPR-RI.

\section{DAFTAR PUSTAKA}

Ardi, R.A.; H.A.; U.S.H., 2017. Pelaksanaan Tugas dan Wewenang Mahkamah Kehormatan Dewan Dalam Penegakkan Kode Etik Dewan Perwakilan Rakyat Republik Indonesia. Jurnal MasalahMasalah Hukum, 6(2), p.5.

Asshiddiqie, J., 2006. Perihal UndangUndang di Indonesia, Jakarta: Sekretariat Jenderal Mahkamah Konstitusi Republik Indonesia.

Habibi, N., 2014. Praktik Pengawasan Etika Dewan Perwakilan Rakyat Republik Indonesia. Jurnal Cita Hukum, II(1), p.47.

Hamzah, M.G., Paradigma Baru 
Penyelenggaraan Pemerintahan

berdasarkan Undang-undang

Administrasi Pemerintahan (Kaitannya dengan Perkembangan Hukum Acara Peratun),

Imani, D., 2016. Penegakkan Kode Etik Anggota Dewan Perwakilan Rakyat Melalui Mahkamah Kehormatan Dewan. Jurnal Masalah-masalah Hukum, 5(3), p.11.

Kansil, C.S.T.K.; C.S.T., 2003. Hukum Tata Negara Republik Indonesia 2, Jakarta: Rineka Cipta.

Kantaparwira, R., 2007. Perihal Ilmu Politik, Yogyakarta: Graha Ilmu.

Marzuki, P.M., 2010. Penelitian Hukum, Jakarta: Kencana.

MD, M.M., 1999. Hukum dan Pilar-pilar Demokrasi, Yogyakarta: Gama Media.

R. Soesilo, 1991. Kitab Undang-undang Hukum Pidana (KUHP serta Komentarkomentarnya Lengkap Pasal Demi Pasal, Bogor: Politea.

Setyowati, E., 2010. Bagaimana Undangundang Dibuat, Jakarta: PSHK.

Sofian, A., 2018. Tafsir Pasal 122 huruf 1 UU MD3: Kriminalisasi "Rakyat", dalam -kriminalisasi-rakyat. Available at: http://businesslaw.binus.ac.id/2018/06/30/tafsir-pasal122-huruf-1-uu-md3.

Susilo, Y., 2012. Penegakkan Kode Etik Dewan Perwakilan Rakyat Republik Indonesia Periode 2009-2014, Jakarta: Universitas Indonesia.

Ziyadi, A., 2017. Pentingnya Pengenalan Pelajaran Norma melalui Strategi Pembelajaran Menyenangkan dengan Humor. In Prosiding Seminar Nasional Tahunan Fakultas Ilmu Sosial Universitas Negeri Medan Tahun 2017. Medan: Universitas Negeri Medan, pp. 1-3. 